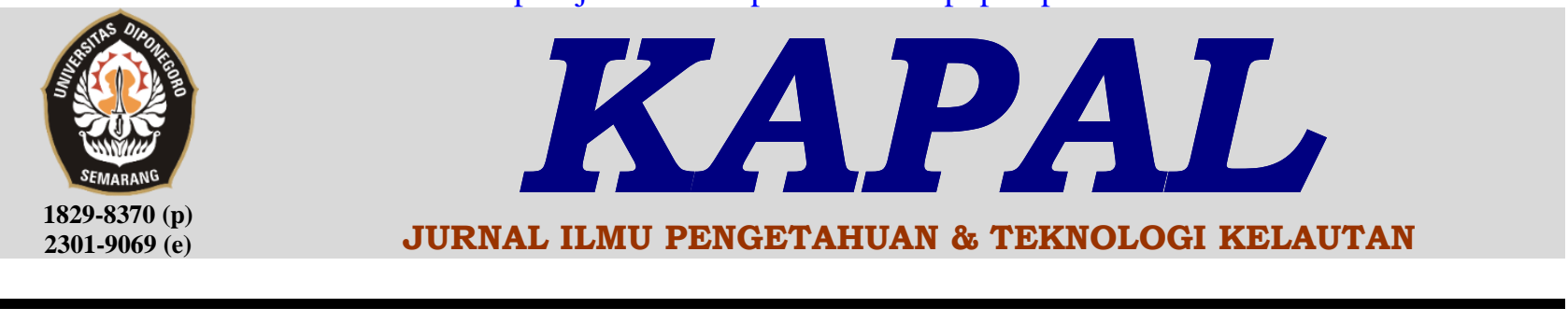

\title{
Analisa Waktu Evakuasi Dengan Metode Advance Pada Kapal Perintis 1200 GT
}

\author{
Kusnindar Priohutomo ${ }^{\left.1)^{*}\right)}$, Budy Rolly Yuwana ${ }^{l)}$ \\ ${ }^{1)}$ Balai Teknologi Hidrodinamika, Badan Pengkajian dan Penerapan Teknologi \\ Jl. Hidrodinamika, Komples ITS Sukolilo, Surabaya, Indonesia 60112
}

\begin{abstract}
Abstrak
Salah satu penyebab besarnya korban jiwa dalam sebuah kecelakaan kapal di jalur pelayaran adalah dikarenakan kurangnya informasi mengenai jalur atau rute evakuasi yang harus dilalui penumpang bila terjadi kecelakaan. Oleh sebab itu kajian mengenai jalur evakuasi utama didalam sebuah kapal saat terjadinya kecelakaan perlu dilakukan dengan cermat. Terutama untuk kapal yang mengangkut banyak penumpang seperti kapal perintis. Pada paper ini akan dibahas mengenai kajian waktu evakuasi penumpang di kapal dengan metode advance berdasarkan ketetapan dari IMO. Untuk proses simulasi menggunakan software Pathfinder 2015. Dari hasil simulasi yang dilakukan waktu embarkasi penumpang adalah 348.03 detik, sedangkan total waktu evakuasi penumpang adalah 2010.03 detik atau sekitar 33.5 menit
\end{abstract}

Copyright (C) 2017, KAPAL, ISSN:1829-8370

Kata Kunci : Kapal Perintis, Kecelakan Kapal, Waktu Perjalanan, Total Waktu Evakuasi

\section{PENDAHULUAN}

Didalam perancangan sebuah kapal dalam hal ini kapal perintis untuk penyeberangan antar pulau banyak hal yang perlu dilakukan kajian lanjut. Termasuk kajian mengenai waktu evakuasi penumpang bila terjadi kecelakaan kapal.

Organisasi Maritim Internasional (IMO) sudah mengatur metode dalam menganalisa waktu evakuasi penumpang kapal dan para ABK kapal. Beberapa asumsi dibuat dan dikembangkan untuk mendukung keakuratan regulasi IMO tersebut. Antara lain (a) kecepatan berjalan orang tergantung pada kepadatan kerumunan orang, tipe dan model jalur serta arah kerumunan, (b) arah pergerakan berlawanan umumnya diperhitungkan berdasarkan counter flow factor, (c) pergerakan orang diasumsikan tanpa rintangan, (d) pengaruh pergerakan kapal, umur penumpang serta keterbatasan ruang gerak akibat asap kesemuanya diperhitungkan melalui safety factor.

Banyaknya terjadi kecelakaan kapal di Indonesia dalam kurun waktu enam tahun terakhir

\footnotetext{
*) Penulis Korespondensi :

Email : kusnindar.priohutomo@gmail.com
}

(2010-2016) sebagaimana daftar yang dikeluarkan Komite Nasional Keselamatan Transportasi (KNKT), mencatat terjadi 54 kasus kecelakaan pelayaran dengan korban jiwa dan material yang tidak sedikit. Hal ini menunjukkan pentingnya pencegahan dan penanganan pada saat terjadinya kecelakaan.

Menurut data investigasi kecelakaan pelayaran tahun 2010-2016 yang dikeluarkan oleh KNKT pada tanggal 25 November 2016 menyebutkan bahwa kecelakan kapal yang terhadi di Indonesia didominasi kapal tabrakan dan kapal terbakar. Dimana dari setiap kecelakaan kapal memakan korban yang tidak sedikit baik korban hilang-meninggal maupun korban luka-luka. Oleh karena itu perlu dilakukan kajian mengenai waktu evakuasi penumpang dikapal agar semua penumpang dapat keluar dari kapal dengan selamat.

Kajian dilakukan oleh Muhammad Andi (2012) untuk menganalisa jalur evakuasi kapal penyebrangan antar pulau. Dimana dari hasil kajiannya jalur evakuasi penumpang pada KMP PM dan KPM J2 memenuhi ketentuan yang disyaratkan IMO, sedangkan efektivitas waktu yang digunakan selama proses evakuasi bergantung pada jumlah 
penumP a g e | 48pang dan jarak tempuh menuju koridor embarkasi, titik kritis jalur evakuasi KMP PM terjadi pada koridor 3 dan koridor embarkasi, sedangkan untuk KMP Jattra terjadi pada koridor emergensi pada main deck.

Kajian lain dilakukan oleh Kutuhara et all (1998) melakukan kajian selama kurang lebih 3 tahun dari tahun 1994. Dimana pergerakan orang menuju tempat evakuasi direkam dan hasilnya adalah kecepatan jalan orang sekitar $1.4 \mathrm{~m} / 2$ pada koridor, $0.7 \mathrm{~m} / \mathrm{s}$ di tangga dan maximum density 3orang/ $\mathrm{m}^{2}$.

Eksperimen lain yang dilakukan oleh Murayama et all (2000), melakukan percobaan dengan sampling laki-laki dewasa dan wanita dewasa. Lebar koridor bervariasi $(1.2 \mathrm{~m} ; 0.9 \mathrm{~m}$; $0.6 \mathrm{~m})$ sedangkan pitch dan roll stabil $\left(+20^{0} \sim-20^{\circ}\right)$. Dari hasil eksperimen didapatkan kecepatan orang pada kondisi kapal static berkisar antara $1.23-1.25$ $\mathrm{m} / \mathrm{s}$. Pada saat kondisi kapal trim, kecepatan berjalan laki-laki dewasa sekitar $0.28 \mathrm{~m} / \mathrm{s}$ dan wanita dewasa $0.71 \mathrm{~m} / \mathrm{s}$.

Lee et all (2004) melakukan kajian tentang kecepatan berjalan secara sendirian dan berkelompok. Hasilnya dari kajian tersebut didapatkan bahwa kecepatan berjalan secara berkelompok berkurang sebesar $20 \%$ dibandingkan dengan kecepatan berjalan sendirian dengan jaraka antar kelompok sejauh $3 \mathrm{~m}$.

Dari beberapa literatur diatas maka penulis mencoba menganalisa mengani waktu evakuasi yang dibutuhkan penumpang pada kapal perintis 1200 GT. Kajian ini perlu dilakukan agar dapat memberikan informasi mengenai waktu evakuasi pada kapal. Apabila waktu evakuasi masih kurang dari yang telah ditetapkan oleh IMO, maka kapal layak untuk berlayar, tetapi bila waktu evakuasi lebih dari waktu yang ditetapkan oleh IMO, maka kapal seharusnya dilakukan kajian ulang mengenai rute evakuasi.

\section{METODE}

\subsection{Aturan IMO}

Sejak tahun 1970, IMO telah mempublikasikan secara intensif ketentuan standart tentang evakuasi penumpang kapal laut, hal tersebut tertera sebagaimana pada ketentuan SOLAS yang berkaitan tentang keselamatan kapal dan jumlah pelampung penolong serta karakteristiknya.

Tahun 1999 IMO menerbitkan MSC Circ. 909 dengan judul pedoman interim analisa evakuasi sederhana, ketentuan tersebut adalah upaya pertama untuk menganalisa secara keseluruhan tentang pergerakan penumpang didalam kapal selama proses evakuasi.
Tahun 2002 IMO menerbitkan MSC Circ. 1033 dengan judul pedoman interim analisis evakuasi untuk kapal baru dan yang sudah ada, aturan tersebut berisi dua metode yaitu (a) analisis sederhana (simplified method) dan (b) analisis lanjutan (advance method).

Dengan menggunakan aturan IMO didapatkan total waktu maksimum evakuasi penumpang kapal yang ditunjukkan pada gambar 1

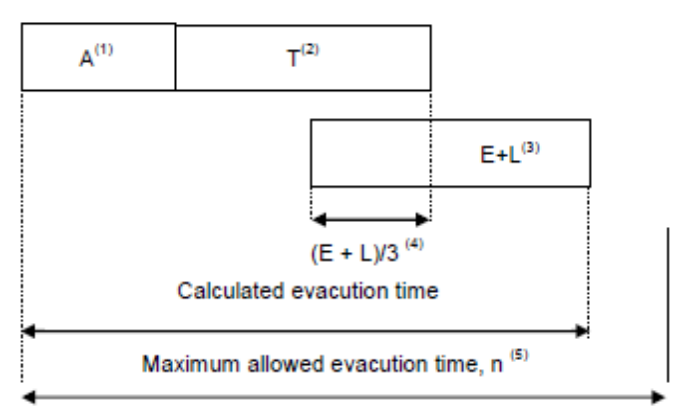

Gambar 1. Waktu Evakuasi Maksimum (IMO, 2002)

Dari skema pada gambar 1 dapat disederhanakan menjadi persamaan sebagai berikut:

$\mathrm{TWE}=1.25 \mathrm{~A}+\mathrm{T}+2 / 3(\mathrm{E}+\mathrm{L}) \leq 60$ menit

Dimana:

TWE = Total Waktu Evakuasi

A = Awerness time / waktu tanggap

$\mathrm{T}=$ Travel time / waktu perjalanan

E $\quad=$ Embarcation time / waktu embarkasi

$\mathrm{L}=$ Launching time / waktu berangkat

\subsection{Studi Kasus}

Kapal yang digunakan dalam paper ini adalah kapal perintis. Kapal perintis adalah kapal pelayanan angkutan yang digunakan pada trayek trayek yang belum memberikan manfaat komersial. Gambar Kapal Perintis ditampilkan pada gambar 2.

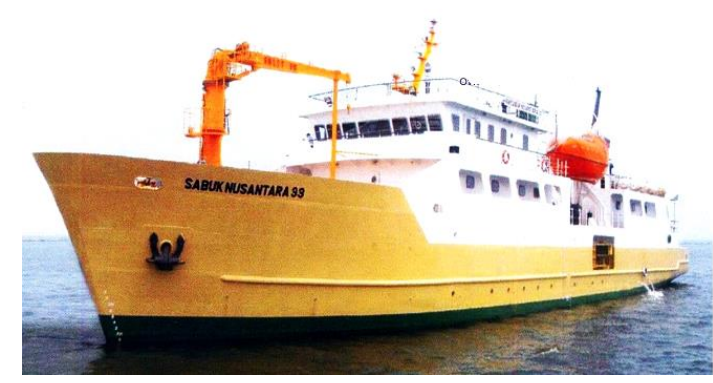

Gambar 2. Kapal Perintis 1200 GT

Pada gambar 2 Kapal Perintis 1200 GT memiliki spesifikasi sebagai berikut: Spesifikasi kapal:

- Panjang keseluruhan (Loa) : $62.8 \mathrm{~m}$

- Panjang Antara Garis Tegak (Lpp) : $57.4 \mathrm{~m}$

- Lebar (moulded) (Bmid) : $12 \mathrm{~m}$

- Tinggi (moulded) (Hmid) : $4 \mathrm{~m}$ 
- Sarat Air d : $2.7 \mathrm{~m}$

- Kecepatan Dinas (Vs) : 12 knot

Kapasitas Penumpang

a) Penumpang

1. Ekonomi: 380 orang

2. Kelas II: 16 orang

3. Kelas I: 4 orang

b) Barang: 50 ton

c) ABK: 70 orang

Untuk memenuhi aturan SOLAS terdapat perlengkapan keselamatan jiwa (life saving appliances) yang terpasang di kapal antara lain:

- Life Boat: 2 unit (kap @70 pax)

- Inflatable Life Raft (ILR) : 25 unit (kap @ 50 pax)

- Life Jacket : 400 set

- Life Buoy (ring penyelamat) : 25 unit

- Dan peralatan lain sesuai dengan regulasi LSA/SOLAS

\subsection{Kondisi Jalur Evakuasi}

Jalur evakuasi pada kapal perintis 1200 GT dibagi dalam 4 deck utama yaitu bottom deck, main deck, crew deck dan bridge deck. Pembagian deck ditampilkan pada diagram hidrolik pada gambar 3

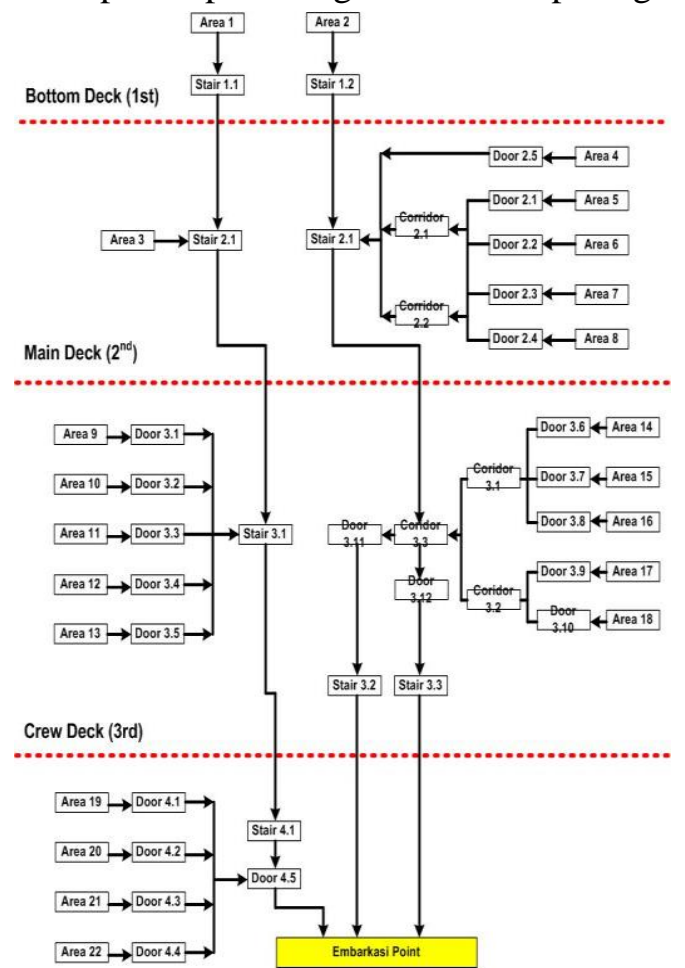

Bridge Deck (4th)

Gambar 3. Diagram Hidrolik Jalur Evvakuasi

Dari gambar 3 dapat dilihat dari atas yaitu bottom deck merupakan deck paling bawah dari kapal, kemudian diatasnya dinamakan main deck, diatasnya lagi dinamakan crew deck dan paling atas dinamakan bridge deck.

\subsection{Kondisi Penumpang}

KAPAL, Vol. 14, No. 2 Juni 2017
Dalam metode perhitungan advance analisis maka penumpang kapal dikelompokkan menjadi beberapa kelompok sesuai dengan kriteria dari IMO pada tabel 2

Tabel 2. Pembagian Penumpang dan Crew Bedasarkan Umur (IMO, 2002)

\begin{tabular}{|l|c|}
\hline \multicolumn{1}{|c|}{ Population groups - passengers } & Percentage of passengers (\%) \\
\hline Females younger than 30 years & 7 \\
\hline Females $30-50$ years old & 7 \\
\hline Females older than 50 years & 16 \\
\hline Females older than 50, mobility impaired (1) & 10 \\
\hline Females older than 50, mobility impaired (2) & 10 \\
\hline Males younger than 30 years & 7 \\
\hline Males 30-50 years old & 7 \\
\hline Males older than 50 years & 16 \\
\hline Males older than 50, mobility impaired (1) & 10 \\
\hline Males older than 50, mobility impaired (2) & 10 \\
\hline \multicolumn{1}{|c|}{ Population groups - crew } & Percentage of crew (\%) \\
\hline Crew females & 50 \\
\hline Crew males & 50 \\
\hline
\end{tabular}

Dari tabel 2 maka daftar penumpang pada kapal perintis dapat dikelompokkan ke dalam beberapa kelompok dan ditampilkan pada tabel 3

Tabel 3. Pembagian Penumpang dan Crew Kapal Perintis

\begin{tabular}{|c|c|}
\hline Kategori & Jumlah \\
\hline Wanita dibawah 30 thn & 30 \\
\hline Wanita 30-50 thn & 60 \\
\hline Wanita diatas 50 thn & 47 \\
\hline Pria dibawah 30 thn & 30 \\
\hline Pria 30-50 thn & 54 \\
\hline Pria diatas 50 thn & 45 \\
\hline Crew Wanita & 15 \\
\hline Crea Pria & 15 \\
\hline
\end{tabular}

Sedangkan kecepatan jalan penumpang kapal mengikuti kriteria dari IMO pada tabel 4.

Tabel 4. Pembagian Penumpang Berdasarkan Kecepatan

\begin{tabular}{|c|c|c|}
\hline \multirow[t]{2}{*}{ Population groups - passellgerels } & \multicolumn{2}{|c|}{$\begin{array}{l}\text { Walking speed on flat terriain } \\
\text { (e.,on, corritidors) }\end{array}$} \\
\hline & Vinimum (m/s) & Maximum (m/s) \\
\hline Females youngerer than 30 years & 0.93 & 1.55 \\
\hline Females $30-50$ years old & 0.71 & 1.19 \\
\hline Females odder thatil 50 yeats & 0.56 & 0.94 \\
\hline Males younger than 30 years & 1.11 & 1.85 \\
\hline Males $30-50$ years old & 0.97 & 1.62 \\
\hline Males older than 50 years & 0.84 & 1.4 \\
\hline
\end{tabular}

\subsection{Skenario Kecelakaan}

Pada paper ini skenario kecelakaan yang 
terjadi adalah kebakaran pada bottom deck, sehingga semua orang dievakuasi menuju bridge deck. Sekoci dan alat keselamatan lain berada di bridge deck. Kapal diskenariokan pada posisi even keel dan tidak mengalamai trim.

\subsection{Simulasi Pathfinder}

Pada simulasi pathfinder yang dilakukan pertama adalah memilih metode yang akan digunakan. Dalam paper ini metode yang digunakan adalah Steering Mode. Dimana penumpang tidak dibatasi oleh antrian pintu atau kepadatan ruang. Sebaliknya, penumpang bergerak menuju tujuan mereka, sambil menghindari dinding dan penumpang lainnya .Mode ini biasanya menghasilkan hasil yang paling realistis secara visual. Ini adalah mode simulasi komputasi yang paling intens.

Pembuatan model uji dengan Pathfinder menggunakan gambar 3D kapal perintis. Pada proses ini simulasi dibagi pada setiap deck

\section{a. Bottom Deck}

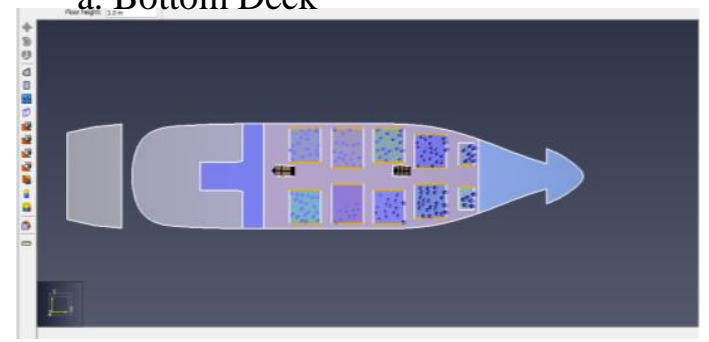

Gambar 4. Pembagian Penumpang Pada Bottom Deck

b. Main Deck

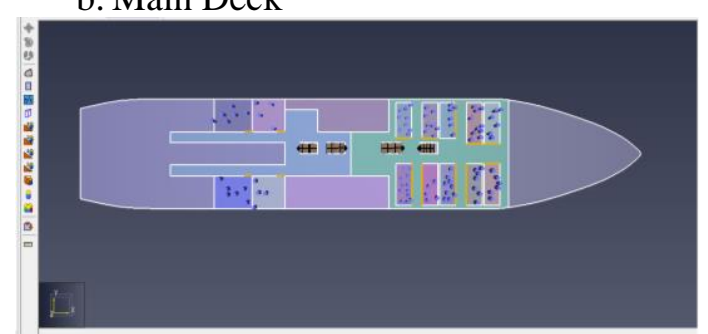

Gambar 5. Pembagian Penumpang Pada Main Deck

c. Crew Deck

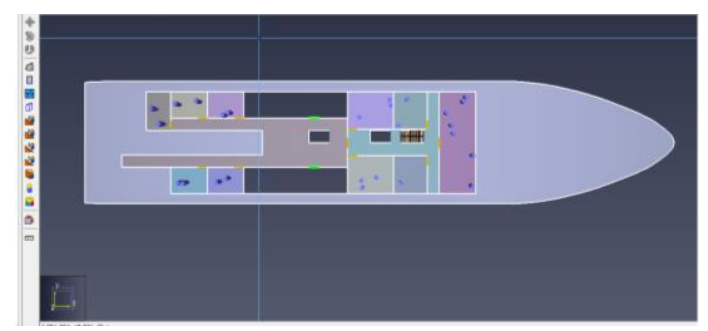

Gambar 6. Pembagian Penumpang Pada Crew Deck d. Bridge Deck

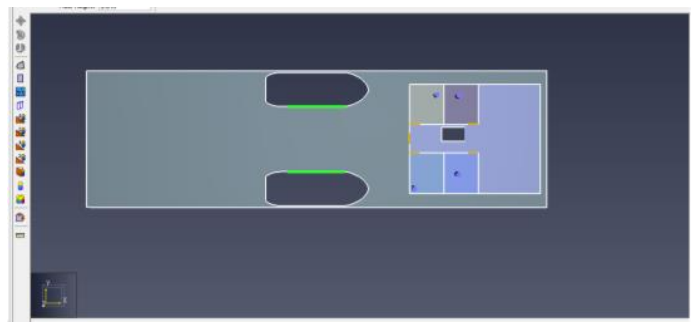

Gambar 7. Pembagian Penumpang Pada Bridge Deck

\section{HASIL DAN PEMBAHASAN}

\subsection{Skenario Evakuasi}

Pada bottom deck terbagi menjadi 2 area yaitu area 1 dan area 2 dan terdapat dua tangga naik ke lantai Main Deck dimana diuraikan dalam tabel 2

Tabel 2. Skenario Evakuasi Pada Bottom Deck

\begin{tabular}{|l|c|c|c|c|}
\hline \multicolumn{5}{|c|}{ Bottom Deck } \\
\hline \multicolumn{1}{|c|}{ Item } & Wc (clear width) & Length & Area & Notes \\
\hline & $\mathrm{m}$ & $\mathrm{m}$ & $\mathrm{m} \wedge 2$ & \\
\hline Bottom Deck-Area 1 & 12 & 11 & 132 & to stair 1.1 \\
\hline Bottom Deck-Area 2 & 12 & 9 & 108 & to stair 1.2 \\
\hline Bottom Deck-Stair 1.1 & 1 & 2.5 & 2.5 & to Stair 2.1 \\
\hline Bottom Deck-Stair 1.2 & 1 & 2.5 & 2.5 & to Stair 2.2 \\
\hline
\end{tabular}

Pada main deck terbagi menjadi 2 area dan 4 kamar yaitu area 3 dan are 4 serta kamar 1 sampai kamar 4 dan terdapat dua tangga naik ke lantai Crew Deck dimana diuraikan dalam tabel 3

Tabel 3. Skenario Evakuasi Pada Main Deck

\begin{tabular}{|l|c|c|c|c|}
\hline \multicolumn{5}{|c|}{ Main Deck } \\
\hline \multicolumn{1}{|c|}{ Item } & Wc (clear width) & Length & Area & Notes \\
\hline & $\mathrm{m}$ & $\mathrm{m}$ & $\mathrm{m} \wedge 2$ & \\
\hline Main Deck-Area 3 & 6 & 13.2 & 79.2 & to Stair 2.1 \\
\hline Main Deck-Area 4 & 6 & 13.2 & 79.2 & to Stair 2.1 \\
\hline Main Deck-Stair 2.1 & 1 & 2.5 & 2.5 & to Stair 3.1 \\
\hline Main Deck-Room 1 & 3.5 & 3.5 & 12.25 & to Door 2.1 \\
\hline Main Deck-Door 2.1 & 1.8 & - & - & to Coridor 2.1 \\
\hline Main Deck-Room 2 & 3.5 & 3.5 & 12.25 & to Door 2.2 \\
\hline Main Deck-Door 2.2 & 1.8 & - & - & to Corridor 2.1 \\
\hline Main Deck-Room 3 & 3.5 & 3.5 & 12.25 & to Door 2.3 \\
\hline Main Deck-Door 2.3 & 1.8 & - & - & to Corridor 2.2 \\
\hline Main Deck-Room 4 & 3.5 & 3.5 & 12.25 & to Door 2.4 \\
\hline Main Deck-Door 2.4 & 1.8 & - & - & to Corridor 2.2 \\
\hline Main Deck-Corridor 2.1 & 1.25 & 16 & 20 & to Stair 2.2 \\
\hline Main Deck-Corridor 2.2 & 1.25 & 16 & 20 & to Stair 2.2 \\
\hline Main Deck-Stair 2.2 & 1 & 2.5 & 2.5 & to Stair 3.2 \\
\hline
\end{tabular}

Pada crew deck terbagi menjadi 10 kamar yaitu kamar 5 sampai kamar 14 dan terdapat 3 tangga naik ke lantai Bridge Deck dimana diuraikan dalam tabel 4 
Tabel 4. Skenario Evakuasi Pada Crew Deck

\begin{tabular}{|l|c|c|c|c|}
\hline \multicolumn{5}{|c|}{ Crew Deck } \\
\hline \multicolumn{1}{|c|}{ Item } & Wc (clear width) & Length & Area & Notes \\
\hline & $\mathrm{m}$ & $\mathrm{m}$ & $\mathrm{m}^{\wedge} 2$ & \\
\hline Crew Deck-Room 5 & 3.7 & 3 & 11.1 & to Door 3.1 \\
\hline Crew Deck-Door 3.1 & 1.8 & - & - & to Stair 3.1 \\
\hline Crew Deck-Room 6 & 3.7 & 3 & 11.1 & to Door 3.2 \\
\hline Crew Deck-Door 3.2 & 1.8 & - & - & to Stair 3.1 \\
\hline Crew Deck-Room 7 & 3.7 & 3 & 11.1 & to Door 3.3 \\
\hline Crew Deck-Door 3.3 & 1.8 & - & - & to Stair 3.1 \\
\hline Crew Deck-Room 8 & 3.7 & 3 & 11.1 & to Door 3.4 \\
\hline Crew Deck-Door 3.4 & 1.8 & - & - & to Stair 3.1 \\
\hline Crew Deck-Room 9 & 10 & 3.4 & 34 & to Door 3.5 \\
\hline Crew Deck-Door 3.5 & 1.8 & - & - & to Stair 3.1 \\
\hline Crew Deck-Room 10 & 2.5 & 3.5 & 8.75 & to Door 3.6 \\
\hline Crew Deck-Door 3.6 & 1.8 & - & - & to Corridor 3.1 \\
\hline Crew Deck-Room 11 & 2.5 & 3.5 & 8.75 & to Door 3.7 \\
\hline Crew Deck-Door 3.7 & 1.8 & - & - & to Corridor 3.1 \\
\hline Crew Deck-Room 12 & 2.5 & 3.7 & 9.25 & to Door 3.8 \\
\hline Crew Deck-Door 3.8 & 1.8 & - & - & to Corridor 3.1 \\
\hline Crew Deck-Room 13 & 2.5 & 3.5 & 8.75 & to Door 3.9 \\
\hline Crew Deck-Door 3.9 & 1.8 & - & - & to Corridor 3.2 \\
\hline Crew Deck-Room 14 & 2.5 & 3.5 & 8.75 & to Door 3.10 \\
\hline Crew Deck-Door 3.10 & 1.8 & - & - & to Corridor 3.2 \\
\hline Crew Deck-Corridor 3.1 & 1.1 & 12 & 13.2 & to Corridor 3.3 \\
\hline Crew Deck-Corridor 3.2 & 1.1 & 12 & 13.2 & to Corridor 3.3 \\
\hline Crew Deck-Corridor 3.3 & 4.8 & 8.4 & 40.32 & to Door 3.12/3.13 \\
\hline Crew Deck-Door 3.11 & 1.8 & - & - & to Stair 3.2 \\
\hline Crew Deck-Door 3.12 & 1.8 & - & - & to Stair 3.3 \\
\hline Crew Deck-Stair 3.1 & 1 & 2.5 & 2.5 & to Stair 4.1 \\
\hline Crew Deck-Stair 3.2 & 1 & 2.5 & 2.5 & to MP \\
\hline Crew Deck-Stair 3.3 & 1 & 2.5 & 2.5 & to MP \\
\hline Crew Deck-Stair 3.4 & 1 & 2.5 & 2.5 & to Corridor 3.3 \\
\hline & & & & \\
\hline & - & & & \\
\hline & 1 & & &
\end{tabular}

Pada bridge deck terbagi menjadi 4 kamar yaitu kamar 15 sampai kamar 18 dan terdapat tempat kumpul (Muster Point) dan tempat launching (Embarcation Point) dimana diuraikan dalam tabel 5

Tabel 5. Skenario Evakuasi Pada Bridge Deck

\begin{tabular}{|c|c|c|c|c|}
\hline \multicolumn{5}{|c|}{ Bridge Deck } \\
\hline \multicolumn{1}{|c|}{ Item } & Wc (clear width) & Length & Area & Notes \\
\hline & $\mathrm{m}$ & $\mathrm{m}$ & $\mathrm{m}^{\wedge} 2$ & \\
\hline Bridge Deck-Room 15 & 3.5 & 2.8 & 9.8 & to Door 4.1 \\
\hline Bridge Deck-Door 4.1 & 1.8 & - & - & to Door 4.5 \\
\hline Bridge Deck-Room 16 & 3.5 & 2.8 & 9.8 & to Door 4.2 \\
\hline Bridge Deck-Door 4.2 & 1.8 & - & - & to Door 4.5 \\
\hline Bridge Deck-Room 17 & 3.5 & 2.8 & 9.8 & to Door 4.3 \\
\hline Bridge Deck-Door 4.3 & 1.8 & - & - & to Door 4.5 \\
\hline Bridge Deck-Room 18 & 3.5 & 2.8 & 9.8 & to Door 4.4 \\
\hline Bridge Deck-Door 4.4 & 1.8 & - & - & to Door 4.5 \\
\hline Bridge Deck-Door 4.5 & 1.8 & - & - & to MP \\
\hline Bridge Deck-Stair 4.1 & 1 & 2.5 & 2.5 & to Door 4.5 \\
\hline
\end{tabular}

\subsection{Perhitungan Waktu Evakuasi}

Simulasi dilakukan dengan menekan tombol running, sehingga software akan melakukan checking, jika tidak terjadi error maka simulasi akan dimulai dan setelah selesai akan didapatkan tampilan 3D dan beberapa grafik yang dapat digunakan sebagai bahan analisa.

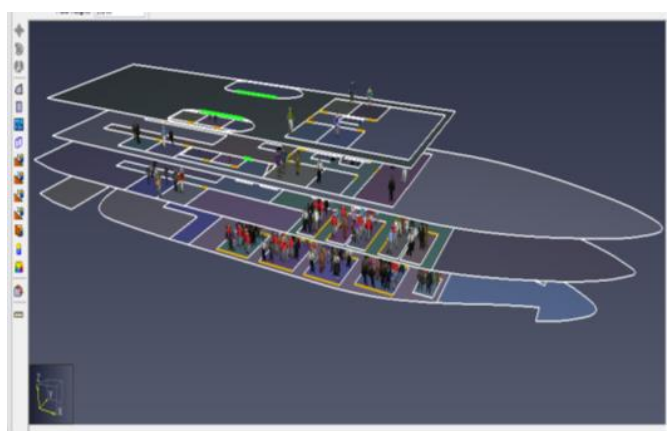

Gambar 8. View 3D Running Hasil Simulasi

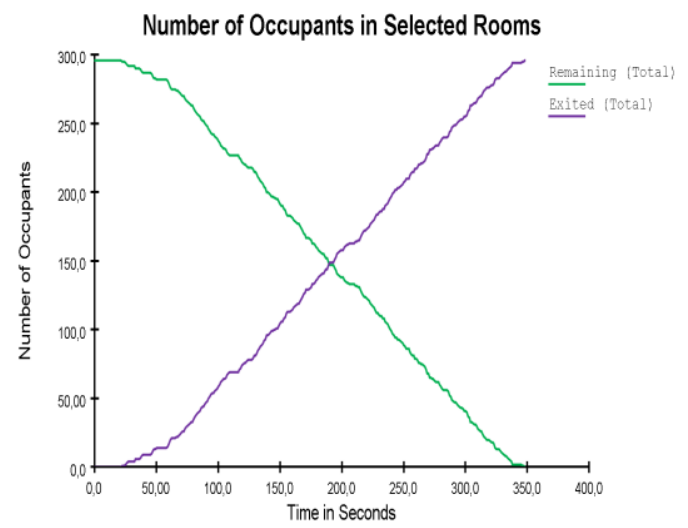

Gambar 9. Grafik Hasil Simulasi Jumlah Penumpang Pada Deck

Dari gambar 9, terlihat bahwa waktu yang dibutuhkan penumpang untuk keluar semua adalah 348.03 detik. Dengan menggunakan persamaan dari IMO yaitu:

Total Waktu Evakuasi $=1.25 \mathrm{~A}+\mathrm{T}+2 / 3(\mathrm{E}+\mathrm{L})$

Dimana $\mathrm{A}=5$ ' (case siang hari)

$\mathrm{E}+\mathrm{L}=$ diasumsikan $30^{\prime}$

$\mathrm{T}=348.03 " / 5$, 8"

Sehingga TWE $\quad=1.25 \times\left(5^{\prime}+5^{\prime} 8^{\prime \prime}\right)+20^{\prime}$

$=2010.03$ "

$=33^{\prime} 50^{\text {“ }}$

Flow Rates for Selected Doors

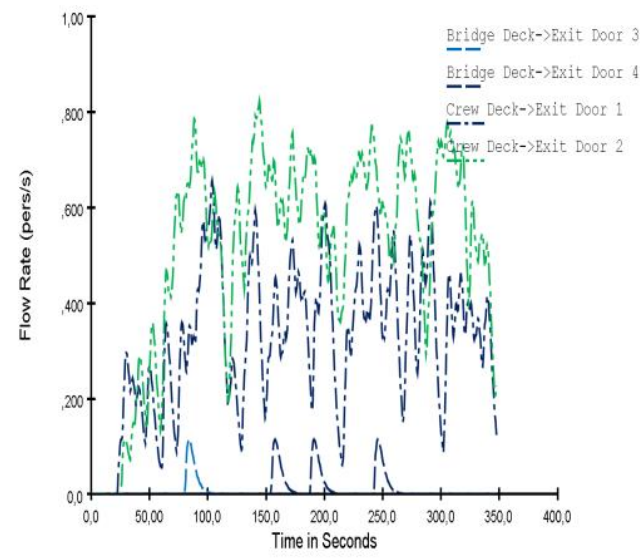

Gambar 10. Grafik Flow Rates Pada Masing-Masing Pintu 
Dari gambar 10, terlihat bahwa pintu paling banyak digunakan adalah pintu Exit Door 1 dan Exit Door 2, dimana mencapai 0.82 persons/detik, hal ini dimungkinkan karena posisi pintu exit yang dekat dengan kerumunan penumpang pada Crew Deck.

\section{KESIMPULAN}

Dengan jalur evakuasi ini penumapang yang ada pada Kapal Perintis 1200 GT memenuhi ketentuan yang disyaratkan IMO dalam upaya penyelamatan penumpang terhadap bahaya kebakaran. Efektifitas waktu yang digunakan selama proses evakuasi bergantung pada jumlah penumpang dan jarak tempuh menuju koridor embarkasi. Dengan simulasi menggunakan Pathfinder (Steering Mode) didapatkan waktu untuk evakuasi menuju embarkation point atau nilai $\mathrm{T}$ sebesar 348.03. Sehingga total waktu evakuasi penumpang pada kapal perintis 1200 GT setelah dilakukan perhitungan sebesar 2010.03 detik atau sekitar 33.5 menit. Total waktu evakuasi penumpang ini masih dibawah standart dari IMO, sehingga kapal layak untuk berlayar mengangkut penumpang.

\section{DAFTAR PUSTAKA}

[1] Fuad Choirul, Ir. Wasis DA, Msc, Phd, "Studi Perancangan Model Evakuasi Sederhana Pada Kapal Penumpang". Seminar Nasional Teori dan Aplikasi Teknologi Kelautan, ITS Surabaya, 2011.

[2] IMO, Interim guidelines for a simplified evacuation analysis on Ro-Ro passenger ships. MSC/ Circ. 909, 1999.

[3] IMO, Interim guidelines for evacuation analysis for new and existing passenger ships. MSC/ Circ. 1033, 2002.

[4] IMO, Interim guidelines for evacuation analysis for new and existing passenger ships. MSC/ Circ. 1238, 2007.

[5] Katuhara, M., et al, "Simulation Of Human Escape On Board-II'. Journal of Japan Institute of Navigation 98, 141-150, 1998.

[6] KNKT, "Investigasi Kecelakaan Kapal Laut Kebakaran di Kamar Mesin KM. Salvia di Perairan Sebelah Timur, Sekitar Pulau Damar, Kepulauan Seribu, DKI'. Laporan Akhir KNKT, 2011.

[7] KNKT, "Investigasi Kecelakaan Kapal Laut Terbakarnya KMP Laut Teduh 2 Di Perairan Sekitar Pulau Tempurung, Selat Sunda, Banten". Laporan Akhir KNKT, 2011.

[8] KNKT, "Data Investigasi Kecelakaan Pelayaran Tahun 2010-2016". Media Release KNKT, 2016.

[9] Lee, D., Park J.H. dan Kim, H. A, "Study On
Experiment Of Human Behavior For Evacuation Simulation", Journal of Ocean Engineering, Vol. 31.pp. 931 -941, 2004.

[10] Murayama, M., Itagaki, T., Yoshida, K, "Study On Evaluation Of Escape Route By Evacuation Simulation" Journal of the Society of Naval Architects of Japan, 188 441-448, 2004.

[11] Muhammad Andi, Paroka Daeng, Sutomo Riswan, "Studi Jalur Evakuasi Pada Kapal Penyebrangan Antar Pulau". Seminar Nasional Teori dan Aplikasi Teknologi Kelautan, ITS Surabaya, 2012. 